\title{
Editorial biofuel: The butanol perspective and algal biofuel
}

\author{
Vedpal Singh Malik
}

Received: 27 June 2014 / Accepted: 14 July 2014 / Published online: 12 September 2014

(C) Society for Plant Biochemistry and Biotechnology 2014

$\begin{array}{ll}\text { Abbreviations } & \\ \mathrm{BF} & \text { Biofuel } \\ \mathrm{B} & \text { Butanol } \\ \mathrm{Y} & \text { Yeast } \\ \mathrm{C} & \text { Clostridium } \\ \mathrm{AF} & \text { Algal bioDiesel } \\ \text { DHA } & \text { Omega-3 Docosahexaenoic Acid } \\ \text { RuBisCORUBISCO } & \begin{array}{l}\text { Ribulose-1,5-bisphosphate } \\ \text { carboxylase/oxygenase }\end{array}\end{array}$

Nowadays, there is renaissance of attention in solventogenic Clostridium to produce biobutanol that can be used as a fuel in an internal combustion engine designed for use with gasoline without modification. Because its longer hydrocarbon chain, it has more energy than ethanol per unit volume. In 1916 during World War I, Chaim Weizmann, a disciple of Louis Pasteur and first President of Israel, produced Acetone-Butanol from starch by fermenting Clostridium acetobutylicum for making of Cordite gun powder. This process was discontinued when butanol could be made from petroleum much cheaper with $\$ 2$ per barrel crude.

Existing bioethanol plants can be adapted to biobutanol production using the same raw material. It is less corrosive and therefore can be transported over pipes. Because, ethanol can only be blend up to $15 \%$ in petrol, there is often surplus of ethanol in the market. Much higher amount of butanol can be used.

Metabolic engineering may allow bacterium to consume a cheaper substrate such as glycerol which is waste product of biodiesel production. Mixture of succinate and ethanol can be

V. S. Malik $(\triangle)$

USDA, 4700 River Road, Riverdale, MD 20737, USA

e-mail: vedpalm@gmail.com fermented to produce butyrate by Clostridium acetobutylicum and Clostridium saccharobutylicum. Succinate is reduced by a two-step reaction to give 4-hydroxybutyrate, which is processed to crotonyl-coenzyme A (CoA) and then butyrate. The genes corresponding to these butanol production pathways from Clostridium were cloned to E. coli.

Sang Yup Lee of KAIST, Dr. Do Young Seung of GS Caltex, a large oil refining company in Korea, and Yu-Sin Jang at BioFuelChem, Korea, have engineered Clostridium acetobutylicum that excretes more than $585 \mathrm{~g}$ of butanol from $1.8 \mathrm{~kg}$ of glucose. DuPont and $\mathrm{BP}$ have a joint effort to make biobutanol and market next-generation biofuels. The Swiss company Butalco is engineering yeasts for the production of biobutanol from cellulosic materials. The US Company, Gourmet Butanol, is exploring fungi to convert organic waste into biobutanol. The art of yeast fermentation is well established and it is already used to accumulate about $18 \%$ ethanol from starch and molasses. Cellulosic ethanol from biomass that pollutes waterways using yeast is intriguing specially to provide rural employment. For this process to be successful the cost of cellulase that converts cellulose to fermentable sugars should be decreased by engineering cellulase. Engineering Saccharomyces cerevisiae with butanol pathway may eradicate the formation of byproducts acetone and ethanol and thus increase butanol yield.

Algal butanol, called Solalgal, in low yield is produced exclusively with solar energy and nutrients and has possibilities. By exhausting molecular biology and chemical engineering competencies, Solazyme's proprietary know-how exploits microalgae's prolific oil production capabilities to costeffectively produce high-value designer oils. Solazyme in a joint venture with Bunge Global Innovation LLC already creates oil and encapsulated lubricant, Encapso ${ }^{\mathrm{TM}}$. Solazyme Bunge Renewable Oils plant industrialized products at three 
large scale facilities, including 2,000 MT/year integrated facility in Peoria, the 20,000 MT/year Iowa facilities in Clinton/ Galva and the 100,000 MT/year facility in Brazil. Solazyme microalgae are heterotrophic that grow in the dark in fermenters by utilizing plant sugars. Unilever to Buy Oil Derived From Algae From Solazyme.

Unilever has contracted to purchase three million gallons of the algae-produced oil from Solazyme for use in personal care products such as Dove and Brylcreem. Motivation of Solazyme is to make oils for products with greater revenue for use in cosmetics, food and petrochemicals. Solazyme will sell to Sephora its Algenist line of Anti-Aging moisturizers for cosmetics for skincare and makeup products. The same strains of algae may make petroleum surrogates at industrial scale. In a joint effort, Solazyme, Inc. and Propel Fuels started selling Algae derived biodiesel at a Valero station in Redwood City, California. Synthetic Genomics Inc. and Archer Daniels Midland Company will commercialize Omega-3 Docosahexaenoic Acid (DHA) from algae for humans and animal feed. The program will be executed by SGI's Genovia Bio business unit, leading producers of algal bio-based food, chemical, and fuel products that has a research and development and phototrophic algae production facility in Calipatria, California near the Salton Sea.

Tel Aviv-based Seambiotic and Seattle-based Inventure Chemical in a joint venture plan to use $\mathrm{CO} 2$ emissions-fed algae to make ethanol and biodiesel at a biofuel plant in Ashkelon, Israel . In Australia, Bio Fuels Pty Ltd (A Victor Smorgon Group company) is developing algae biofuels in Victoria for use into BioMax biodiesel produced by Smorgon Fuels. Another Australian Company is Algae. Tec developing algae technology to produce bio diesel and green jet fuel.

Biofuels for aviation are starting to look promising For instance, Policies of the state government of Minas Gerais in Brazil are encouraging the cultivation, extraction and processing of the native macaw palm (Acrocomia aculeata) as viable cradle of oil for producing biokerosene. Macaw palm can yield up to 6,200 kilograms of oil per hectare while sequestering 4-5 times more carbon than Eucalyptus camaldulensis. Macaw palms oil could exceed global palm-oil market without compromizing food productionor natural ecosystems

Algal Biodiversity should be exploited to produce products for social consumption. Wild type algae should be screened for secretion of various fatty acids specially hydroxyl acids, protein content and superior Ribulose-1,5-bisphosphate carboxylase/oxygenase, (RuBisCORUBISCO) for engineering into crop plants. The application of recombinant DNA technology to industrial algae is already happening. The pace of mind boggling technology is fast and opportunities are only limited by imagination. 